\title{
4 \\ A Jewel in the Austrian Crown
}

My mother, Elfriede, was two-and-a-half years older than my father, Rudolf Girschik. She had the more constant influence on her children when we were growing up. He set a fine example of dedication in his responsibility for his family and in how he performed his work. During informal moments of endearment, they were Friedel and Rudi, although my mother preferred her formal name.

While they came from German and Austrian backgrounds where the same basic language was spoken, by temperament, environmental influence and acculturation they were quite different people. It is interesting to think that Hitler wanted to reunite Germans and Austrians as the 'one people' he believed them to be. He was, of course, Austrian himself. He used a false mythic conceptualisation that bypassed historical and cultural realities to justify his invasion of Austria, and to create in 1938 the notorious Anschluss (connection).

There was little opposition. People knew of the great Holy Roman Empire that in the distant past had encompassed both areas. The shared language of modern Austria and Germany gave Hitler a mandate for unification. Contemporary pictures suggest that Austrians in Vienna gave the Anschluss overwhelming support.

But there were incipient cultural faultlines between the two countries. These were found in microcosm in the relationship between Rudi and Friedel. They increasingly surfaced as conflict during World War II, which deepened the differences. We children often cringed as we watched this Austro-German alliance between two volatile people of forceful character descend into frustration and misunderstanding. A typical exchange would 
go like this: 'But you are only a German country girl, Elfriede!' 'And you Viennese, Rudolf, have the greatest talent in the world for advertising yourselves and Vienna!'

My father's words used to fall like bricks. My mother's were shot as keen arrows to the heart of her antagonist. 'You're so crude! Your manners belong to the language used by labourers on a building site,' was one riposte.

Beyond the walls of their home they were all charm. As one of my friends was to put it in the 1960s: 'I love your parents. The energy levels always rise a few degrees when they enter the room.' That's how they ended up: too forceful for their children.

In the early years of their marriage, fractures between them were cemented over. Her Protestant upbringing and his Catholicism were lesser obstacles than Rudolf's career. The most damaging influence on them, however, was the vengeful intervention of what may be seen as 'other people's wars'. My parents were essentially private citizens within their respective nationalities. They never participated in political activity or public warfare in any sense of the word. Like so many disengaged people, they were caught up in the larger currents of the twentieth century, like leaves ripped by autumn winds from the trees. This is not special pleading on their behalf. They, like me and so many others, lacked the understanding and the courage to deal with the negative forces unleashed by the War. I cannot leave a truthful memory of them presenting me with a shining example of political courage. I lack the evidence to offer them either praise or blame. During that War, I was a child to whom much adult activity was like the title on the spine of a book. The text, the heart of their thoughts and feelings, was closed to me.

I have nevertheless been able to piece together, from their own spare and occasional words, the circumstances that led them to a life away from 'home'. Mother was the more obliging storyteller.

What drew their paths together? They both had family roots in Czechoslovakia. In Europe, a road can now be followed between their homelands, and it moves through that former nation. As young adults, they worked in the same distant foreign country. Yet nothing could have been more different than their experience in the years when they were growing up. 
Born on 5 August 1907, Elfriede was raised in the agricultural village of Steinkirche in German Lower Silesia. She was the eldest child of Emma, born Friebe, who married the widower Friedrich Bittnar. Elfriede was born into a close-knit family. Friedrich had brought a daughter into the household, and he appears also to have had an older son.

Ancestors seem to have been settled in that part of the world for a long time. The village was named after its mediaeval church, and became for a period a Bohemian possession. Later, during the seventeenth century, it was staunchly Protestant. By then it was also Prussian. Still later, it became part of a united Germany.

Is it possible that before Elfriede's mother's marriage an association already existed between her mother's father, Gustav Friebe, and her own? Both men worked as railway pointsmen, or signal attendants. Perhaps the stress of caring for a stepchild and a baby led Emma to give Elfriede over to be raised by her parents, who lived in another part of the village.

To be given away like that was one of the grievances Elfriede carried over into later life.

While the Bittnar family had once enjoyed a degree of wealth because of their involvement in the weaving for which Silesia was noted, by Elfriede's time, her family no longer benefited from this cottage industry.

Her father spoke fluent Russian, a useful talent in a place as vulnerable as Lower Silesia. The great Russian bear of Eastern Europe was both feared and admired. Russia itself was too close for comfort.

Friedrich's work often kept him away from home for long periods, as he travelled to the country's borders. His son Otto was born to Emma two years after Elfriede.

Friedrich owned a simple two-storey whitewashed stone house without running water. The family had to lug in water for cooking, bathing, cleaning and washing. From an early age, the children acquired habits of thrift and knew the value of work. In winter, the Bittnar washing was dried in the attic. The family was, however, sufficiently well-off not to have to share the ground floor with their animals. 
While Friedrich brought in wages, the family lived in modest comfort, although World War I made things difficult and the post-War Depression caused periods of real hardship. The family owned or had access to a plot of land beyond the village where vegetables were grown. They were thus sometimes better off than their urban-based relatives.

Family bonds appear to have been strong in the Friebe-Bittnar alliance. Emma had at least four brothers. Her children had 'aunts' who visited her home, but I do not know whose sisters or wives they were. Emma's brother Wilhelm had set himself up as a baker in Berlin and married the beautiful fair-haired daughter of two of his customers, an expatriate Ukrainian couple. Ties with relatives in Berlin always remained strong. Connections to urban life and Friedrich's interest in Russia (which his daughter Elfriede absorbed) brought the cultural currents of the day into the family's parochial existence. For instance, Elfriede's grandmother had a habit of sulking and not speaking when she was offended. Her husband used to coax her into a better mood with songs from Johann Strauss' operetta, Nights in Venice: 'Komm in die Gondel mein Liebchen, oh steige doch ein?

Elfriede inherited her grandmother's propensity for not speaking for long periods when hurt. It is a product, I believe, of a repressive upbringing. But she absorbed enough of her grandfather's sense of humour, which her own father shared, to enable her to rise, resourcefully and imaginatively, above these disapproving sulks. Elfriede's character also made her strong enough to overcome catastrophes in later life.

The Lutheran Church strongly influenced village life. The members of Emma's family not only regularly attended church, but were taught from the Bible to live by Christian precepts. Elfriede spoke of her mother as a good Samaritan to strangers. Later in life, she recalled that Emma never turned away hungry people from her door. She sat them at her table, whether beggar or friend. Thus began a tradition of hospitality from which both her daughters were to draw inspiration that reached women of subsequent generations.

Elfriede's father had been raised a Hussite, a follower of Jan Huss, the most important Czech religious reformer of the fifteenth century, who died in 1415. He also belonged to die Brüderschaft, the Moravian Brotherhood. Although Friedrich was said to have been a man of deep humanity and 
gentleness in his dealings with his wife and children, Elfriede remembered that his religious formation determined that a Sunday at home was observed as seriously as a funeral.

The family's Lutheran members, however, exercised the dominant influence. Pagan superstitions had not been eliminated from rural Silesia despite centuries of Christian teaching. The two systems co-existed. It was considered dangerous to hang out washing for some days after Christmas in case the god Odin's horses caught their hooves in the washing lines as they galloped by. They could bring tragedy to a family. Animals were always to be treated with care. On Christmas Eve, all farm animals were to be indulged with special food in honour of their presence during the birth of Jesus in the Bethlehem stable.

When Elfriede was nine years old, during Christmas 1916, Russian soldiers came to Steinkirche. They picked the little girl up off the street and carried her aloft through the snow-bound village, as the Christ child. This was a Russian custom. The Russians were prisoners-of-war, assigned to work in the fields of local farmers. Friedrich Bittnar had given them permission to carry his daughter as part of their traditional ritual. He could converse with them in their own language.

In 1918 tragedy struck the family. Friedrich and his two children were wrongly diagnosed as having typhus, and were taken back to the hospital where they were then said to have contracted the illness. It was liceborne, carried by soldiers returning from World War I. They died within a fortnight. Emma was said to have lost so many relatives that the undertaker wept at the graveside. Elfriede still experienced fits of melancholy fifty years afterwards, every time she heard the train driver blow his whistle passing by the village. It was the custom to acknowledge a death and a burial in this manner in these tightly knit village communities.

Emma, who was pregnant at this time, was so shocked by the disaster that her hair turned white 'overnight'. She even tried to drown herself in the local quarry. Twelve-year-old Elfriede ran after her mother in her nightdress, pleading with her to return home. For a long time after that, Elfriede feared going to sleep at night.

Much later in life, a train blowing its whistle near her home in rural Western Australia in the 1960s could transport Elfriede back to Steinkirche and the deaths in her family. 
On 14 November 1918, Emma gave birth to a daughter whom she named Else after her dead stepdaughter. Strange as it may seem to us, it was then not unusual to name a newborn child after one who had died earlier. There was a high rate of infant mortality, and certain names recurred in families. Elfriede had admired her stepsister with her Titian auburn hair. She was said to have been a beauty. Elfriede mourned her death and also the loss of her father, to whom she had always been closest. At a time when children were frequently beaten, he had only ever smacked her once when, with her customary quick tongue, she had called him a 'three-coloured tomcat' because of the red streaks in his beard and the two shades of brown in his hair and eyebrows.

When Emma lost her husband and stepdaughter, Elfriede was obliged to leave the high school in Breslau she had started that year, as well as her home with her grandparents. She had to come back to look after her mother. The loss of her schooling and the way she felt she was being pushed around contributed to further feelings of grievance. She also felt displaced by the birth of the baby.

Baby Else seemed to be showered with loving protection. She was a sweetnatured child. As Elfriede was to recall, while she herself was used to wearing the hand-me-down clothes of her older sister, Else was dressed in 'new silk and velvet'. Given Elfriede's talent for dramatisation, one can substitute 'new cotton and wool'.

Elfriede saw herself as put upon. As she remembered it, she was always being reprimanded by visiting aunts for her sharp tongue and the wilful behaviour which could 'bring trouble to her mother'. She increasingly saw herself as an alienated rebel. In later life she experienced recurring fits of melancholia. Perhaps this was rooted in the tragedy of 1918 and its consequences. It was no doubt nourished by a typical diet of Silesian Romantic literature, of which Joseph von Eichendorff was the most noted exponent. These writings were infused with a love of Nature, and romanticised the freedom of the wanderer. Elfriede devoured such work as her spiritual sustenance.

In her early thirties, another blow would further blight her spirit.

But as a teenager, she had little time to wallow in self-pity. She was part of a hard-working household without water. Her mother took to her bed for long periods, both before and after the birth of the baby, suffering fits of depression despite the joy of her splendid new child. When baby 
Else was old enough to be left in the care of her older sister, at about the age of two, Emma would set off on occasional long journeys in the company of friends to visit two of her brothers. Her thirteen-year-old daughter would be left in charge of her two siblings as well as the young children of the travel companions.

Elfriede resented this arrangement. She remembered it as scandalously irresponsible. As she saw it, Emma sacrificed her daughter's education to her own needs. Daunted by being called on to be so responsible so young, she remembered being scornful when her mother returned from her long absences. Elfriede had made the little ones happy by re-arranging the furniture and sleeping with everyone together on the floor. Then suddenly her mother would take over again, and reimpose her own arrangements.

The idea for the communal sleeping is a clue to my mother's resourcefulness. It demonstrates her talent for improvisation. As a teenager, she sewed clothes and hats, hoping to become a dress designer. When her twelveyear-old cousin Gertrud arrived alone from distant Berlin with a placard around her neck announcing 'Steinkirche via Breslau', passengers looking out were astonished to see Elfriede, a young teenager, with her family's goat and ducks dressed up in the jackets and hats she had sewn for them.

When the situation at home became more stable, Elfriede was sent to acquire secretarial skills in the nearest city. Emma knew of the hardships faced by a widow after her husband dies. Since 1918, she had scratched together a living by taking in washing, ironing and sewing to make ends meet. She argued that a woman had a better chance for independence with ready access to paid work, rather than from mere education.

Elfriede must already have been quite independent in character. She cut her long hair short in the new manner of city girls, even though this was considered 'in the manner of tarts'. She kept up her interest in fine literature and, once she began to earn wages, collected books. The village school had taught the girls well. Elfriede could recite long narrative poems many years after she had left. The school laid the foundations for her respect for learning and her love of literature.

She was about eighteen, I think, when she took up a position on an estate at Märzdorf. There she did secretarial work and became the companion of an eighty-year-old woman of aristocratic lineage. She travelled with her in her carriage to social functions. The old woman taught her all manner 
of domestic refinements and thrifty budgeting for a large aristocratic household. All clothing was mended with such artistry that additions became invisible. Even bedsheets were darned.

From parts of the estate, Elfriede could see the steeple of her village church. She was beset with nagging Heimweh (homesickness). Her stories suggest she may not have gone home very much. Märzdorf was perhaps six kilometres away as the crow flies, but much further when following the road, which wound in part along the flood-prone banks of the Oder. Her work arrangements seem to have provided little regular time off.

Through Elfriede's talent for vivid description, I later got to know something about the older women of my mother's family. They laughed and sang with open-throated ease, using humour and repartee to lighten the domestic routine, which they approached with almost religious zeal. They created clean, comfortable spaces in their houses, not so much to be admired as to offer Gemutlichkeit, comfortable, cosy conviviality. My mother told me: 'We were expected to become Herdetiere (herd animals)'-that is, people with a strong sense of community, a strong culture.

After World War II, when Silesia had been handed over to Poland, and Elfriede's sister Else had joined our household in Australia, the sisters indulged their predilection for wine and spirits and nostalgic reminiscences about their days in Silesia. They admired the fine craftsmanship of its artisans and the way in which the seasons were celebrated. They remembered the celebration of a fruitful harvest or the winter solstice which used to hail 'the return of the sun' with huge bonfires and burning cartwheels that were rolled down the hill. My mother spoke of the fragrance of pine branches brought indoors at Christmas when snow lay thick on the ground. They were decorated with the finest strips of silver 'angels' hair' and dotted with real wax candles in little tin stands. Polished fresh apples that had been stored in the barn beneath a layer of hay adorned the tree, together with gingerbread hearts coated in chocolate.

In winter when times were good the cosy Kacheloven or tile oven warmed the house day and night. Spring arrived with such exuberant return of growth that 'the oldest donkey kicked his legs in the air'. On 1 May, the young ones danced around the maypole in their regional costumes.

These were seasonal festivals celebrated all over Europe. But everyone valued what was special to their region. 
Girls were all brought up in the same way as my mother. Acculturation involved habit-forming activities such as the scrubbing of floors, the starching and ironing of all bed linen, and the baking of honey-based Bienenstich and butter-crumbed Streusel cakes for Sunday's breakfast after church. Das Schlesische Himmelreich, a regional specialty of pork stewed with dried fruits, was less remarkable for its flavours than for the many occasions on which it appeared on the table. Some of my greatgrandmother's aphorisms have endured over four generations. I recall my mother's exchange with one of my daughters in the 1970s: 'Do not allow anger to erupt. Do as my grandmother cautioned: "Take a mouth full of cold water and wait until it boils!"”

Young Anthea’s retort, some hours later, was: 'Grandmama—the water!'

The women of my family excelled as cooks and sewed and gardened with enthusiasm. Conversely, they also shared a pervasive melancholy, a talent for withdrawing into protracted silences, of making others guilty by their refusal to be open about what had gone wrong. My brothers and I have acquired some of their reclusive melancholy.

But there was always an over-arching pleasure in the companionship of that rural environment, of groups of people picking mushrooms and berries in the forests and going on excursions into the mountains singing in harmony to lutes as they walked.

It was into this robust, but often temperamentally ambiguous environment, that my mother was born. She absorbed its essence as she grew up.

I now ask myself why, if Elfriede found this environment so oppressive, in later life I only ever heard her speak the dialect of her people with her sister Else.

I know she looked back on those days in the village with mixed feelings. Both sadness and love suffused her memories. She found an oppressive 'parish pump' atmosphere of gossip, of people 'minding other people's business' and of dictating how others should behave. Central to this was what people assumed to be the 'pillow talk' between the pastor and his wife. They seemed to know what everybody had told her husband in confidence before it became common knowledge. The pressures of a married clergyman and his wife, together with other constraints, made 
village life stifling for Elfriede. She often recalled how poor the family became after her father's death, and the limitations this imposed on their lives.

Emma always wanted to join the young ones, whether welcome or not. She accompanied them to local dances, taking part in the fun as well as acting like a chaperone. Grandmother, too old to come along, would gaze enviously from the attic window.

Around 1930 the members of Emma's household moved into an apartment in Neumarkt Platz, the market square of Breslau. Possibly Elfriede and Otto, the wage-earners, contributed to the rent. Breslau was a vibrant, cultured city with a theatre, opera house, book and craft shops, botanic gardens, zoo and public baths. The Austrian empress Maria Theresa had once exclaimed that Silesia was the jewel in Austria's crown. Breslau was prosperous because it lay between trade routes. It benefited from abundant natural resources, especially coal from Upper Silesia. So many traders and their animals moved into parts of the city from the country each week that the council had to control them.

During the 1930s, Hitler's crazy regime harnessed the groundswell of Germanic feeling and mythology in the re-education and re-tribalisation of the German nation. Set on the eastern frontier of Germany, Silesia was vulnerable to foreign invasion and ethnic cleansing. Traditions contributed to a sense of identity. The children of Steinkirche had been raised with a strong love of their locality and a sense of being Silesian German.

It is interesting to note how long traces of Silesian culture have endured in South Australia's Barossa Valley. Back 'home' even local landforms had mythological significance, like the western mountain range known as das Riesengebirge (the mountains of the giants) in which the gentle giant Rübezahl strode with seven-league boots. You had to be careful not to get trampled. Das Eulengebirge (the mountains of the owls) were also a talking point. There was mystery and there was magic beyond natural life.

I do not know what year it was when Elfriede went to work in Stamboul (Istanbul). It could not have been later than 1933. She got a position there on the recommendation of her employers at Märzdorf. Their illustrious relative, Baron von Tucher, whose family had been painted by Holbein and Goya, was the German envoy to Turkey. With their base in Hamburg, 
the Tucher family had won its standing through the Hanseatic League's cloth trade, just as merchants elsewhere had achieved aristocratic standing through fortuitous trading and as pioneer bankers.

Before her departure for Turkey, Elfriede spent time with her cousins in Berlin and with a close friend from Steinkirche, Johannes Móller, who was studying law (probably in Breslau) and who introduced her to other law students. With them she tasted the heady cabaret life of Berlin's fashionable city centre, on Unter den Linden (under the linden trees).

Elfriede later said that to be part of that scene between the Wars was like 'dancing on top of a volcano'. One of her close friends was her cousin Vera, a successful dress designer who was to migrate to the United States. Elfriede's closest female friend also migrated there and was to end up in prison for participating in civil rights activities.

Elfriede herself was much taken by the powerful anti-Fascist art of Käthe Kollwitz, the wife of a doctor who treated the poor of Berlin. At the same time, the girl from Steinkirche began to dress fashionably, in the urban style. While an element of sophisticated snobbery appeared in Elfriede's demeanour, she never lost her attachment to the land.

Her talent for quick-witted repartee and her fondness for reciting from memory passages from literature prepared her for the company she was to keep among expatriates in Turkey. She was employed in Stamboul to supervise the domestic staff of the German legation and to deal with the envoy's personal correspondence. Despite her domestic role, she mixed freely with visiting diplomats from other nations with whom she was sometimes invited to sit at table. She also cooked for them when the legation's cook took maternity leave. With her Turkish boyfriend, she visited the local restaurants, getting him to purchase recipes for her to cook at the legation.

Elfriede mixed with German academics from the university. She often spoke of the classy boating parties she went to on the Bosporus and the Sea of Marmara. She never mentioned party politics. (After she had left, the next envoy was a political appointee of Hitler's.)

This is the time my parents met. When Rudolf, the young civil engineer from Vienna, called at the legation, she compared his unaffected charm with the seedy sophistication of diplomats and academics. That was how 
she was to explain it to me some forty years later. 'He was like a fresh mountain spring, unaffected and spontaneous.' Her rural childhood had left deep roots.

Rudolf and Elfriede became lovers. I was born four months into their marriage.

Rudolf was born on 3 March 1910 in Vienna into a pious Catholic family. He had been raised with the indulgence often accorded a youngest child. While his older brother Karl was destined to take over the family workshop, where small leather goods were manufactured to be sold at their retail outlet in central Vienna, Rudolf was lucky. He attended a Technical High School and then the Museum of Technology, to qualify for a diploma in civil engineering.

His mother left her mark on the family's domestic life, but her husband ruled the household with strict Catholic authority. Before her marriage to Karl, Maria (born Bresnitzer) had performed in repertory in the city of Graz, as an actress and singer.

Since her family lived off their leathercraft business in the spa resort of Bad-Ischl in the larger neighbourhood of Salzburg, Maria's family may well have had business connections with the Girschiks of Vienna. On the Ahnen Pass (genealogical passport), which Hitler made obligatory after Germany's Anschluss, Karl's family is traced back to the eighteenth century, always with Austrian residence.

The name Girschik obviously has an older Slavonic origin. Its Czech equivalent means butcher, although there were no butchers in my father's family, who almost all made a living from working with leather. I am not aware of any Jewish connections, although Girsch sometimes appears as a Jewish name elsewhere.

In 1956, when I visited relatives in Vienna, that family was the only one in the Vienna phone book. I sometimes wonder whether tinkering with evidence was possible, since I see no evidence in this document thataccording to my father-one male elder of the direct branch of his family came from Prague, with antecedents in Moravia. Perhaps this was his mother's father. 
At least two, or maybe all three of Rudolf's sisters were given sound instruction in music. Their eldest daughter, Maria Anna ('Marianne'), was taught the piano by a pupil of Franz Liszt. She was already an accomplished pianist before her marriage to Oswald Dittrich, whose father, Franz Rudolf Dittrich (1861-1919), had studied under Anton Bruckner, whom he succeeded as court organist in Vienna. Franz Dittrich's first musical appointment was to Kyoto where, as musician and impresario at the court of the Emperor, he was the first person to introduce Western classical music to Japan. No one in my family knows why his marriage or cohabitation with a Japanese woman, Kiku Mori, ended, or what happened to his two children, Otto Mori (born 1892) and Yashiko Miyoko (born 1894). We know that his son became a violinist, probably Japan's first. Franz Dittrich remarried in 1900, to the twentyyear-old Katherine Kriegl who, in 1901, produced Oswald Dittrich, his only offspring in Vienna.

While the family life of my father Rudolf was closely and rigidly supervised, under his father's Catholic piety and rigid paternalism, the cosmopolitan influence of Viennese urban life left sufficient mark on Rudolf for him to be able to happily leave home. He was not dependent on either his family or what Vienna stood for. He nevertheless retained a singular fondness for both when he lived abroad.

Rudolf Girschik's sister Anna ('Annie'), the second oldest, was to becomeuntil she turned fifty-the leading soprano in concert-style orchestral Masses by Schubert and Bruckner, Mozart and Haydn. She performed in the city's neo-Gothic Votifkirche. She could not become 'professional' since she was obliged to work in the family's shop during the week.

Karoline ('Li'), Rudolf's third sister, was to marry a teacher and cellist, Franz Berg. Rudolf himself learnt to play the violin. He admired the music of his city's great composers, but made nothing special of it. The religion and music of my father's family were just another part of ordinary living: something people took for granted, not something to boast about, or to acknowledge with passion in times of cultural drought. The distinction between 'classical' high-brow, and popular 'folk' music was not significant. Familiar with classical music, Rudolf was just as likely to be enlivened by a proficient brass band as by a visit to the Volksoper up the hill from where he lived. 
He was equally relaxed about his Catholic religion, proving himself over time a convert to pragmatic rationalism. He was a collector of 'correct information', never a dogmatic idealist.

As a teenager after World War I, young Rudolf had been boarded out every summer at the rural retreat of a Protestant Danish doctor's family, which had claimed him on behalf of a Scandinavian aid project. This supported children from central Europe left destitute at the end of the War. He learned to speak simple conversational Danish. Rudolf remained in grateful contact with these people all his life. Like most western European high school children, he studied languages: French, English, Italian, in that order. He thought it necessary that everyone learn more than one language and also kept in touch with Professor Pucci, his French and Italian teacher, all his life.

Rudolf loved observing and experiencing foreign ways. After he graduated in civil engineering, he found work on buildings around Vienna uninspiring, with secure work hard to come by.

When he heard about the expansion of railways in the Middle East, in 1933 he rode his bicycle from Vienna to Baghdad in search of opportunity. No stories survive from that marathon. One cannot even be certain that he rode all rhe way, as he later inferred. On the one hand I came to know him years later as an honest man of few, blunt words interlaced with moments of sentimentality; on the other, I discovered his penchant for joking, and for telling the occasional tall story to test our faith in him.

The prospect of working in a Muslim country did not deter him. Arriving in Baghdad, he was told to try his luck in neighbouring Turkey. He came to Stamboul with a camera, a sketchbook diary and the notebooks in which he composed 'verses'. Perhaps they were written to a distant beloved, for his only daughter was named in part, so he said, after one of his Danish girlfriends.

His first assignment was to supervise the construction of the Swedish embassy in Ankara, the new Turkish capital. Either before or during this project, he must have met Elfriede Bittnar at the German legation in Stamboul. 
After the embassy was completed, he was awarded membership of the Knights of Vasa from the King of Sweden, in person. This no doubt guaranteed him further work. When a contract was signed for his supervision of a railway project, about 100 kilometres north of Ankara, he was able to offer Elfriede financial security.

But there was no smooth passage to their long-term relationship. As Elfriede was to comment ruefully in later life, suggesting the historical basis of conflict between Austria and Germany: 'The war between the Empress Maria Theresa and the Prussian King Frederick II continued into our marriage.'

Rudolf's patriotic Austrian family opposed his marriage to his German lover vehemently, by letter. This was in spite of the fact (or perhaps because) she was expecting his child. They argued against her Protestant upbringing, and that she was unconventionally older than he and a sophisticated woman of the world who had 'led the innocent Rudolf astray'.

My mother reluctantly agreed to convert to Catholicism to placate them, though this offended her sense of fairness.

Rudolf remained attached, and even beholden, to his family all his life. They had coddled him as their youngest. This was especially so after he lost the sight in one eye when, as a three-year-old, he had taken a hammer to a glass.

In Turkey the independent Elfriede appeared to be in control of every situation. His glass eye was never an issue. Her heart was essentially compassionate. She focused on his good qualities. Worldly sophistication was of secondary value. And what could a pregnant woman in a foreign land do on her own?

All their lives, despite their temperamental ups and downs, the couple were to retain a genuine attachment to each other. Their happiest years, however, came at the beginning.

Elfriede gave her consent to becoming a Catholic to the papal legate in Turkey, Cardinal Roncalli, a man of 'such magisterial bearing, charisma and genuine modesty' that he removed all her scruples about the Catholic Church and its beliefs. She fell on her knees in true acceptance. 
Elfriede Bittnar and Rudolf Girschik were married in the chapel of the Austrian boys' high school in Stamboul. That same day, in late February 1935, they travelled by steam train across the snow-bound plain of Anatolia. In the next few months their places of residence followed Rudolf's work, beyond Çankiri and back. They settled in the village in a narrow valley. Their home was the top floor of a stone house beside the poplar-lined railway line. It was here that I was born, at home, at the height of summer. Rudolf delivered me himself.

Photographs attest to the bliss of my parents. They gave me the doublebarrelled name of Helga-Maria, with Christine to follow. For a long time I was simply Hasi (little rabbit). The long name also shrank in common usage. Not only his mother, but several men in Rudolf's family, had Maria as a second name. Mother said that Maria was her choice after her favourite (male) poet, Rainer Maria Rilke. I know that Hasi was for my long legs and protruding ears, which my parents tried to tame for a while with sticking plaster. Maria also soon fell out of use and was offered only when I earned special merit.

Rudolf's twenty-eight-year-old wife became an innovative homemaker, with few resources. She cooked cakes in the lids of saucepans for the bachelor engineers Rudolf kept bringing to their modest table. One of his wedding gifts for her had been a huge Austrian cookery book, a gastronome's delight from middle-class Vienna. But she preferred simple things.

Bonded perhaps by their love of the earth, Elfriede won the friendship of Turkish women in the neighbourhood. She learned respect for their customs. But she used to speak of amusing misunderstandings. When a man suddenly appeared, the women would grab the hem of her dress and throw it over her face. They then would cover their own faces with their veils, as etiquette demanded. Elfriede was thus displayed with her underpants exposed, far ruder than her face according to Western custom. Was it then that she began to construct one of her favourite sayings, that 'manners are morals'?

Well into winter, and nine months after the couple's arrival in Çankiri, Rudolf followed the promise of work in Iran. He drove my mother and me in an open car through Iraq and Syria. In Mosul I became so ill that my parents hurried to a Dominican monastery to have me baptised a Catholic. The incident illustrates that Rudolf's Catholic obligations, 
and his devotion to the beliefs of his family, ensured that no child of his was to be deprived of the spiritual consolation promised to all Catholics who receive the Sacrament. I survived to enjoy the Turkish name Yildiz (star, or Stella in English) given me by the Christian stranger, the Turkish godmother who was called in off the street to act as witness.

Rudolf and Elfriede otherwise did not attend church in the Middle East. Perhaps there were few Catholic churches in Iran. After their arrival in Tehran, we began life in the upper floor of a rented apartment.

My parents associated at first with Austrian and German expatriates who lived in the city, and observed with them the unfolding of events in German politics. Like most German-speakers of their generation, both my parents initially commended Hitler's social programs, aiming to bring everyone in Germany employment during the deep, disastrous Depression after World War I. I cannot recall that either of them ever subscribed to Hitler's aggressive nationalism, to his hijacking of government, to his theories of the superiority of the 'Aryan race' and that the future belonged to Germany. They came to Iran for Rudolf's work and immersed themselves in that country and its cosmopolitan work force with great energy.

Caring mostly alone for an inquisitive young child in a foreign country, and entertaining her husband's many guests kept Elfriede well employed. At that period of their marriage Rudolf from Vienna was proud of his talented wife from Breslau. His admiration for her never died, although he was to express it less and less openly over time. I loved my father with unbridled enthusiasm in my early years.

We could not know then how profoundly the coming War would affect our lives. 
This text is taken from At Home in Exile: A Memoir, by Helga M. Griffin, published 2021 by ANU Press, The Australian National University,

Canberra, Australia.

doi.org/10.22459/AHE.2021.04 